\title{
JUURNAL_RU
}

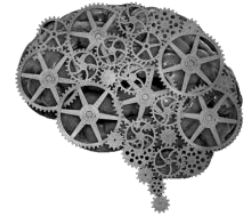

COMPANY GROUP "INTELLEKT"

\author{
Стрельникова Л.Ю. \\ Армавирский лингвистический сочиальный институт \\ Армавир, Россия
}

doi: 10.18411/lj2016-3-77

\section{Становление метапрозы в дискурсе игровой поэтики В.В.Набокова}

Набоковский метароман вобрал в себя тенденции экспериментальных творческих поисков в литературе XX века, идя по пути преодоления реализма к символизму с его поисками высшего мира до нигилизма авангардизма и следом за ними модернизма и постмодернизма. Определяя жанровые особенности набоковского творчества, В.Ерофеев называет метароман Набокова основной формой художественной системы писателя, говоря, что «романы писателя группируются в метароман (или, иначе сказать, надроман, объединяющий несколько романов), обладающий известной прафабулой, матрицируемой, репродуцируемой в каждом отдельном произведении при разнообразии сюжетных ходов и развязок, предполагающих известную гибкость решений одной и той же фабульной проблемы» [4, т.1,с.13]. Можно сказать, что метароман, беря за отправную точку индивидуальное эстетическое сознание автора, структурируется как многоплановый текст с усложненным внутренним построением («текст в тексте»), способный к продуцированию новых смыслов.

Объясняя специфику новаторской поэтики Набокова, М.Медарич также говорит о метаповествовательном характере произведений писателя как актуальной идее в культуре XX века, выраженной в противостоянии детерминистской концепции «жизненной полноты и миметической убедительности» с новаторскими установками, «а именно, что всякое истинное произведение искусства в действительности говорит о себе самом» 
обуславливая всеобщий «игровой подход автора к тексту и читателю» [7, с.454].

По наблюдениям Н.Букс, «отличительной чертой набоковской поэтики является богатая вариативность ее приемов, подвижность их художественных функций, непрерывная перекодировка смыслов, символов в системе каждого романа» [1]. Подобный тип метаромана с многослойной нестабильной структурой С.Давыдов назовет «текстом-матрешкой», имея в виду принцип «саморефлексии повествователя», создающего свой творческий мир, когда «литературная установка сдвигается на писательский процесс этого повествования...» [3], при таком построении романной формы основной темой творчества становится сам процесс создания художественного произведения, искусство служит себе самому. С.Давыдов так характеризует набоковский тип метаромана, или «сверхромана»: Литературное произведение, которое содержит один или несколько написанных героем текстов, я предлагаю называть «текстматрешка», по аналогии с куклой-матрешкой. «Внешний» авторский текст соответствует внешней кукле, в то время как «внутренний» текст героя, вошедший в авторский текст, соответствует внутренней кукле (или куклам, если текстов несколько)» [3]. Анализируя некоторые произведения Набокова, С.Давыдов определяет роднящие их типологические метапоэтические черты, а именно, «общая тема творчества $<\ldots>$ и то, что их героями являются писатели, сочинения которых частично или полностью вошли в виде “внутреннего" текста» [3].

На метароман как господствующую форму набоковского творчества указывает в своем обширном исследовании «Русский модернизм. Очерки исторической поэтики» М.Липовецкий, называя его синтетическим жанром, как заметил ученый, «поэтика Набокова, начиная с ранних романов и чем дальше, тем активнее была насыщена метапрозаическими элементами» [6,c.52], а роман «Дар» выделяется как «самый яркий образец русской метапрозы» [6,с.54]. Таким образом, метароман выполняет надстроечную функцию по отношению к общепринятому пониманию классического романа, наслаивая в себе 
многочисленные текстовые модели без определенных структурных ограничений, разыгрывая литературные коды существующих произведений, демонстрируя при этом «общий игровой подход к тексту, проявляющийся, с одной стороны, в обнажении авторской роли в литературной конструкции, тематеизации процесса собственного литературного оформления; а с другой - во включении читателя в творческую игру» [6,с.53].

Набоковская метапроза органично вписывалась в развивающуюся концепцию экспериментального искусства новых форм и их художественного воплощения в соответствии с эстетическими кодами модернизма, а затем и постмодернизма. Художественная позиция писателя как автора метароманного жанра демонстрирует игровую избыточность, опровергающую рационализм в искусстве, вводя симулятивные образы, в целом «философия симулятивности как fiction имманентно присуща метапрозе - и Набоков ее выразил в полной мере» [6,c.9]. Набоков строит свой метароман по принципу интертекста - игры, в процессе создания которого «истина бытия заменяется бытием изображения» [2,c.82] собственного эстетического мира, в котором соединяются цитаты, образы, сюжеты разных культурных кодов, что и дает новые комбинации, как говорил о специфике создания произведения писатель, «так кусочки картины вдруг мгновенно сходятся у вас в голове, причем самой голове невдомек, как и отчего сошлись все части...» [8,с.473], процесс творчества в его представлении совершается на уровне подсознания, а результат как таковой не имеет значения, так как главное показать превосходство искусственного над реальным.

Набоков создает особый тип метаромана - это игровой многомерный роман, в нем, как в игре, изображаемая псевдореальность превосходит классический способ воспроизведения реальности в ее причинно-следственных закономерностях и характеризуется саморефлексивностью и пародийной интертекстуальностью, как говорил Набоков в «Даре», литература «должна «пробираться по узкому хребту между своей правдой и карикатурой на нее» [9,т.3,c.180], что соотносится с бахтинской концепцией карнавала, когда 
разыгрывается сама жизнь, ведь именно в атмосфере игры «автор свободно создает собственный мир» [10]. Таким образом, набоковский метароман представляет собой ярко выраженную манифестацию игры, писатель опрокидывает детерминистские критерии творчества, следуя карнавальной дихотомии комического и трагического. Изображенным на страницах романов марионеточным героям Набоков чаще всего уготавливает трагическую роль: исчезает в никуда Ганин («Машенька»), выпадает из окна Лужин («Защита Лужина»), обрекает себя на смертную казнь за убийство Герман («Отчаяние»), в некий потусторонний мир исчезает Цинциннат («Приглашение на казнь») и т.п. В карнавальном перевертыше происходит деконструкция реальности и выведение еe в сферу трагикомической гиперреальности, симулирующей действительность, проявляясь в виде фантазмов автора, маркируя игровое существование произведения без соотнесения изображаемого с подлинностью бытия. Набоковская гиперреальность не воспроизводит явления и человека, а симулирует их в игровых образах без подобия реального, автор наделяет своих героев актерскими функциями, «делая акцент <..> на едва заметном искажении реального образа, происходящем в точке, занятой наблюдателем и дающим возможность построить симулякр» [4,c.335], демонстрирующий отсутствие подлинности в изображении мира, но приобретающий значение авторского мифотворчества, в рамках которого симулируемая реальность выглядит как истинная. Такими «наблюдателями»-марионетками, создающими свои фантазмы, выступают герои произведений писателя (Ганин, Лужин, Цинциннат, Федор, Герман и т.д.), они демонстрируют свое творческое подсознание, сигнализируя о распаде физического бытия и установлении власти симулятивных форм и образов.

Примерами таких надстроечных метароманных конструкций следует считать шахматную гиперреальность-потусторонность в романе «Защита Лужина», идеальный, но существующий лишь в фантазиях Цинцинната мир Тамариных Садов в «Приглашении на казнь», внутренние тексты в романе 
«Дар» - это вымышленные рассказы начинающего поэта Федора о воображаемом путешествии его отца по Азии, а также пародийный роман о Чернышевском. Ассоциативная память в «Машеньке» становится основой для выстраивания авторского мифа о счастливом прошлом эмигранта Ганина в России и иллюзорного будущего с Машенькой в какой-либо европейской стране.

Метароман как модернистская структура усиливает значение индивидуального авторского сознания в творческом процессе, писатель довлеет над своими персонажами и появляется в тексте через своего героя«представителя», ставя себя в центре создаваемого им эстетического мифа, призванного вознести роль художника и устранить в агональной творческой игре соперников-соавторов (читателя, героя), в результате чего должен остаться только авторский метатекст и его Творец, Magister Ludi, устанавливающий правила игры, приравненной к искусству, игра же становится «способом бытия самого произведения искусства» [2,c.147], что и является основополагающим принципом неклассического искусства. 


\section{Литература:}

1. Букс Н. Эшафот в хрустальном дворце // О русских романах Владимира Набокова. М.: Новое литературное обозрение, 1998 / URL. http://coollib.com/b/240152/read

2. Гадамер Г. Понятие игры // Истина и метод: Основы философской герменевтики. М.: Прогресс, 1988. 704 с.

3. Давыдов C. «Тексты-матрёшки» Владимира Набокова / URL. http://libatriam.net/read/355750/

4. Делез Ж. Платон и симулякр // Ж.Делез. Логика смысла (вторая половина). М.: Издательство Раритет, Екатеринбург: Деловая книга, 1998. 480 с. C.329-347.

5. Ерофеев В. Русская проза В.Набокова // В.Набоков. Собр.соч. В 4.т. Т.1. М.: Правда, 1990.

6. Липовецкий М.Н. Русский модернизм. Очерки исторической поэтики. Екатеринбург: Уральский государственный педагогический университет, 1997. 317 с.

7. Медарич М. Владимир Набоков и роман XX столетия // М.Медарич / В. В. Набоков: PRO ET CONTRA. - СПб.: Русский Христианский гуманитарный институт, 1997. 960 с.

8. Набоков В. Искусство литературы и здравый смысл // В.Набоков. Лекции по зарубежной литературе. - М.: Издательство Независимая газета, 1998. 512 c.

9. Набоков В. Дар // В.Набоков. Собр. соч. В 4 т. М.: Правда, 1990.

10. Набоков В. Набоков и театр (Дмитрий Набоков) // Лекции о драме. М.: Азбука-классика, 2008.

URL. http://royallib.com/book/nabokov_vladimir/lektsii_o_drame.html 